\title{
The Analysis of Development Disparities Inter Districts/City in Special Region of Yogyakarta (DIY) Province 2003-2013
}

\author{
Anisa Nurpita \\ Diploma of Economics and Business Universitas Gadjah Mada \\ anisa.nurpita87@gmail.com \\ Aulia Agni Nastiti \\ Diploma of Economics and Business Universitas Gadjah Mada \\ auliaagninastiti@yahoo.co.id
}

\begin{tabular}{l|l|l} 
Received: March 2016 & Accepted: April 2016 & Published: May 2016
\end{tabular}

\begin{abstract}
One of the objectives of regional economic development is to increase the economic sector, in which the increasing of economics sector will be beneficial for society. This indicator is important to recognize the condition of the economy in particular region in given period indicated by GDRP (Gross Domestic Regional Product) data of the region or area. Since the enactment of the autonomy then the local Government has bigger role in managing regional economic potential that exists in its territory. Economic growth is one of indicators that affect economic development. Economic development in substance aims to increase public welfare. Yogyakarta province is one of cities on the island of Java with the level of GDRP that keeps increasing each year since 2003 until 2013.

In the development process there are also regions that have abundant of natural resources but lacking in human resources, and yet there are also regions that are otherwise lacking in terms of natural resources however have abundant in human resources, both in quality and quantity. This situation then leads to the distinction in development that resulted in the economic growth and disparities welfare in each region. The research also aims to identify the patterns of economic growth according to Klassen Typology and describe the level of regional disparities between districts/cities in Special Region of Yogyakarta (DIY) Province. The methods of analysis used covers analysis of the Klassen Typology, inequality Williamson Index, and inequality Theil Entropy Index. The results showed classifications according to Klassen Typology, Yogyakarta is concluded in the category of advanced and fast growing area. The index disparities show a pattern of increasing. This implies that development in district / cities in Special Region of Yogyakarta (DIY) Province are increasingly uneven.
\end{abstract}

Keywords: economic growth, klassen typology, regional disparities, williamson index, entropi theil index. 


\section{INTRODUCTION}

Economic growth is one of indicators that affect economic development. Economic development in substance aims to improve public welfare. According to Todaro (2000), the main objective of economic development in addition to creating economic growth extended, is also to remove and reduce the level of poverty, income inequality and unemployment rate.

Employment opportunities for residents and communities will provide income to meet their needs. Economic development is defined as a series of businesses in economy to develop its economic activities so that more infrastructures available, companies are increasing and growing, level of education the higher and technology advanced. As the implications of this development is expected to increase job opportunities, rising income levels, and higher level of prosperity (Sukirno, 2006).

Disparities between area are often becomes a serious problem. Some areas achieved significant growth, while some other regions experiencing slow growth. Areas that did not experienced the same progress due to lack of sources. There is a tendency of the owners of capital (investors) select urban areas or regions which have infrastructure facilities such as transportation, electricity networks, telecommunication networks, banking, insurance, and skilled workers (Barika, 2012). Besides, also there is inequality and redistribution of revenue sharing from the Central Government to regions such as provinces or subdistrict (Kuncoro, 2004).

Therefore, the results of development should be able to be enjoyed by all people as a manifestation of increased prosperity in a fair and equitable way. Development policy is implemented to achieve higher economic growth by utilizing the potential of the existing resources (Noviana, 2014). According to Sukirno (2004), one instrument for measuring economic success an area is its economic growth. The economy in a region will increase from year to year due to the presence of the addition on production factors.

Sutarno and Kuncoro (2003), disparities caused by the concentration of economic activity in spatial. Barika (2012), Population growth and investment significantly effect positive on regional disparities.

Government through the Law No. 25 of 2004 about National Development Planning System state that national and regional development planning is an activity that carrying out continuous and sustainable following certain patterns based on the results of careful study based on appropriate situation and conditions. Comprehensive and completed development needs to be implemented, so that development goals can be optimally achieved.

The capability of each region to build their respective regions is different, since it is influenced by differences in the potential of resources available such as human resources, natural resources, artificial resources as well as social resources. In the development process some areas that have abundant natural resources but less in human resources, on the contrary, there are also regions that less in terms of natural resources but 


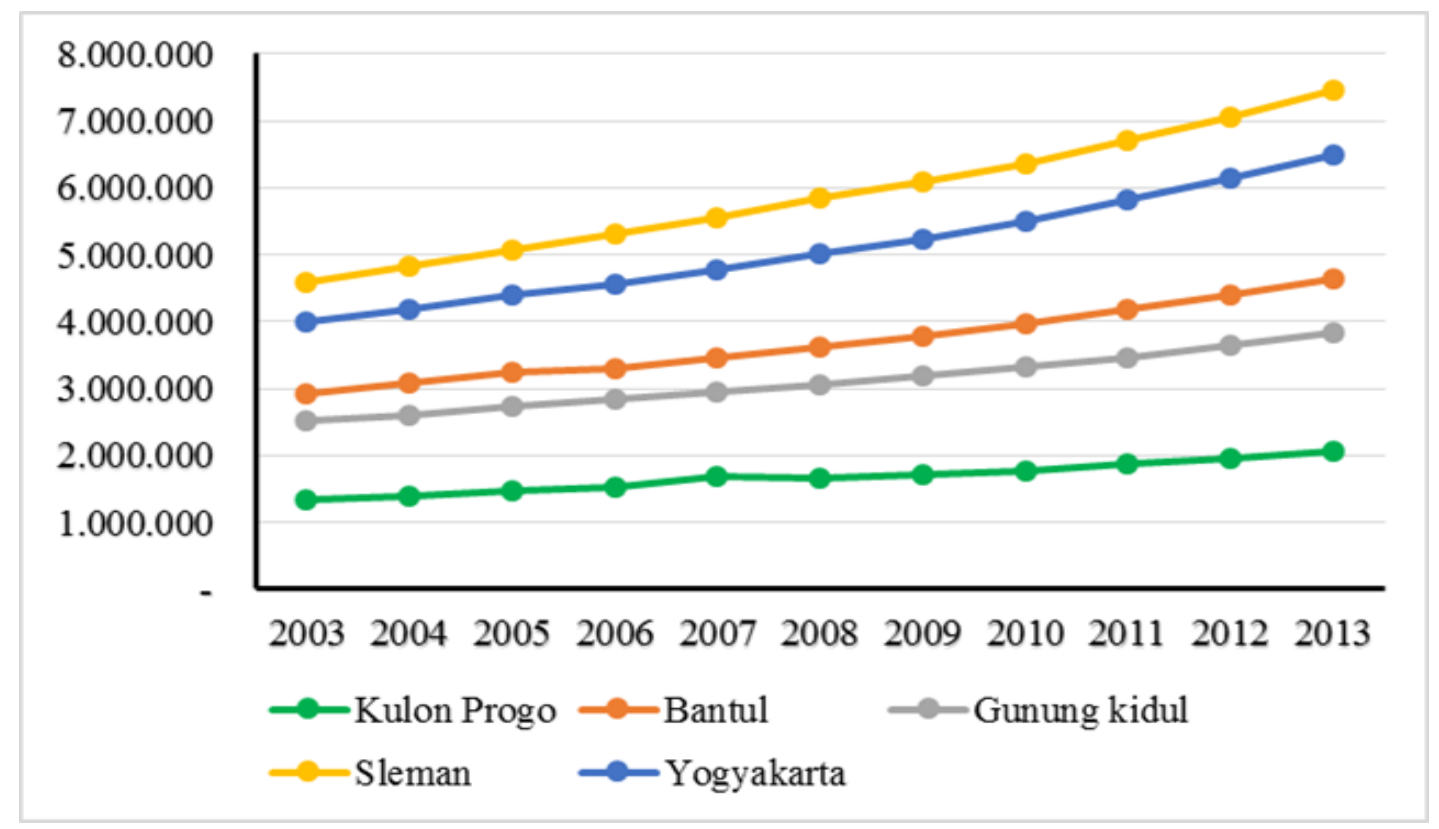

Figure 1. GDRP on the constant price according to districts/ city in Special Region of Yogyakarta (DIY) Province 2004-2013 (Rp billion).

abound in human resources, both in quality and quantity. This situation causing the differences in development that resulted in economic growth and inequality levels of welfare in each region.

The disparities between regions also occurred in Special Region of Yogyakarta (DIY) Province which consists of four districts and one city, namely Kulonprogo district, Bantul district, Gunungkidul district, Sleman district, and the city of Yogyakarta. One indicator of the development success is economic growth can be measured by Gross Domestic Regional Product (GDRP). The evidence of discrepancy between the district/city can be seen first from the GDRP, population, and GDRP per capita. Gross Domestic Regional Product (GDRP) defined as the quantity of added value produced by all units of business in an area, or the sum of all values goods and services in the end which is in generate by all economic unit in a region.
In the last ten years, GDRP in each district/ city in Special Region of Yogyakarta (DIY) Province has increased every year (Figure 1). The district/ city which has the highest GDRP was Sleman, and Kulon Progo District was the lowest one. In 2003 the GDRP Sleman District was $\mathrm{Rp} 4,60$ trillion, and then increase dramatically to Rp7,47 trillion by 2013 , while GDRP Kulon Progo District of Rp1,34 trillion in 2003 increased to Rp2,06 trillion by 2013 . The increasing of GDRP in Kulonprogo district was extremely low when compared to Sleman district. Thus, can be indicators of the disparities in economic growth.

One of indicators for measuring the level of population's prosperity in one region or areas is by observing the GDRP per capita. GDRP per capita is obtained from the results of quotient between added value produced by all the eco- 


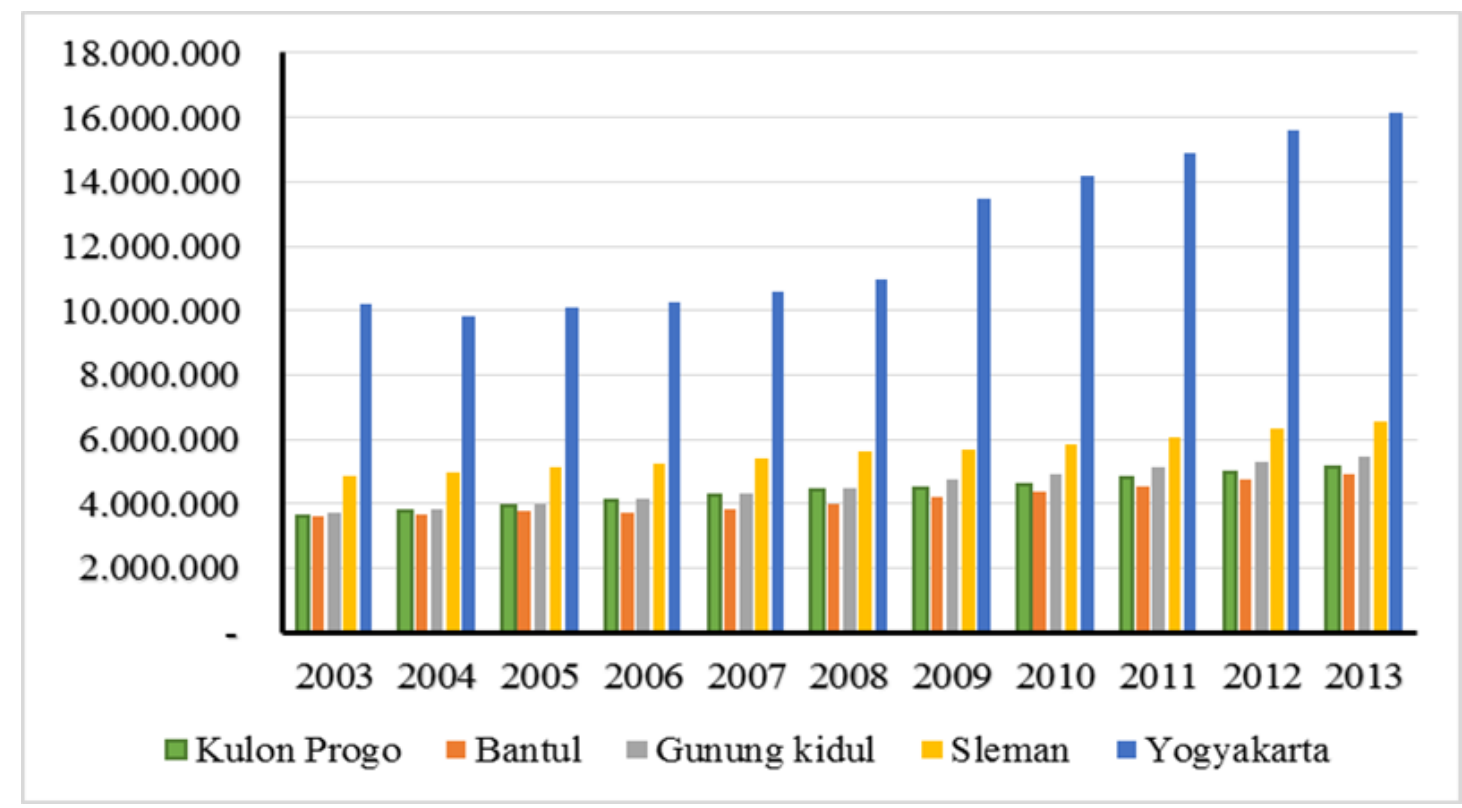

Figure 2. GDRP per capita on the Constant Price According to districts/city in Special Region of Yogyakarta (DIY) Province 2004-2013 (million). Source: Statistic Center of Yogyakarta (analyzed data)

nomic sector in an area (GDRP) and population of the middle of the year.

GDRP per capita is an indicator for measuring the level of community welfare in particular region. According to Tarigan (2005), GDRP per capita is total GDRP in an area subdivided by population in the region at the same year. Higher level per-capita of GDRP in an area indicates higher level of welfare of community, and conversely lower level per-capita of GDRP in an area indicates lower level of welfare of community.

Figure 2 shows that there was difference in GDRP per capita which happened in Special Region of Yogyakarta (DIY) Province. This was evident that the city of Yogyakarta dominates in terms of GDRP per capita. Then in the second position was Sleman district. While, other districts their GDRP per capita much lower than Yogyakarta city and Sleman district. GDRP per capita Yogyakarta city in 2003 amounted to Rp10,18 million increased to Rp16,14 million by 2013. GDRP lowest per capita was Bantul district amounting to Rp3,62 million in 2003, increased to Rp4,91 million by 2013.

According to Krisnantiya (2014), disparities in Special Region of Yogyakarta (DIY) Province caused by economic growth and unemployment rate. Stiglitz (2013), the increase in inequality was the result of wider spacing between the highest income group with another. The reason of increasing is the behavior of rent seeking. Rent seeking behavior will be made part of a larger development enjoyed by high income groups so that lower income group will be enjoyed less.

From the comparison between GDRP, population, GDRP per capita above, it can be seen that the comparison numbers between districts/ city from the highest and the lowest is very high. 
It showed that the level of inequality between the districts/ city in Special Region of Yogyakarta (DIY) Province were also high, because there are under development area while there are already very advanced area. This study aims to analyze position the economic growth of each district/ city based on economic growth in Special Region of Yogyakarta (DIY) Province and Gross Domestic Regional Product (GDRP) per capita and regional disparities between district and city in Special Region of Yogyakarta (DIY) Province over the past 2003-2013. Thus, this research studying Development Disparities inter Districts in Special Region of Yogyakarta (DIY) Province in 2003-2013. Sutarno and Kuncoro (2003), studying economic growth and disparities between subdistrict in Banyumas regency in 19932000. The data used was secondary data by applying Williamson Index and Entropy Theil Index. The result showed, observations in the period 1993-2000 occurring trend of increasing inequality, both are analyzed with Williamson index or with entropy Theil index. This imbalance caused by the concentration of economic activity in spatial. Kuznets hypothesis applies in Banyumas Regency.

Barika (2012), researching on the analysis of inequality and regional development district/ city of Bengkulu province in 2005-2009. The data used are secondary data from BPS province of Bengkulu by applying analysis instrument of Klassen Typology, Williamson index, Entropy Theil Index, and Linear regression analysis. As the results showed that the population growth $(X$
2) and investment (X 3) have positive significant effect against regional imbalances of Bengkulu province. Meanwhile, government spending (X 1) has no significant effect.

Caska dan Riadi (2008), researching on growth and economic development disparities between regions in Riau 2003-2005. The data used was secondary data with analysis of Klassen Typology, Williamson Index, Entropi Theil Index, and U Kuznet curve. The results of the research was during observation in period 20032005 , there was inequality of development that were not significant based on the index of Williamson, while according to the Theil entropy index, the inequality of development was small which means still the onset of equitable development each year during the period of observation. As consequence, Kuznets hypothesis in Riau was not proved as it presented from inverted $U$ curve.

Noviana (2014), researching on The Analysis of Economic Growth Rate and The Level of Income Inequality inter districts/ city in Special Region of Yogyakarta (DIY) Province in 20032012. The data used were secondary data coherently a whole years. Analysis Instrument used were Williamson Index, Entropi Theil Index, Location Qouetient (LQ), Shift Share, and Klassen Typology. The results of the study showed that inequality income inter districts/city in Special Region of Yogyakarta (DIY) Province concluded as high $(>0,5)$ with index Williamson of 0.71 and analysis of Theil Entropy index of 4.35. While inverted Kuznet curve depicted the relationship growth and inequality index was not yet 
applicable in Special Region of Yogyakarta (DIY) Province. Kusuma (2011), researching on The Analysis of The Structure of Economic Growth and Inequality Income Inter Areas of Central Java Province in 2004-2008. This study used secondary data with instrument analyst of Location Qouetient (LQ), Klassen Typology, Williamson Index, and Entropi Theil Index. The results of research explained that there were still many areas in the Central Java province that included as disadvantaged area. Inequality of income inter areas in Central Java province in 2004-2008 conclude as high $(>0,5)$ and experienced a declining trend.

\section{Economic Growth}

Economic growth is one of indicators that affect economic development. According to Kuncoro (2004:129), economic growth is a process of increasing output per capita in the long term. So the percentage growth of output must be higher from the percentage of addition in population and there is a tendency in the long term that the growth continues. According to (Tarigan, 2007:46), definition of tighter economic growth explains that economic growth must be sourced from internal process of economic activities in the area.

Todaro (1994:282) argues that economic growth can be defined as the steady process of productive capacity of economy that increased all the time to produce bigger national/ local income levels (Pirade, 2006:11). Whereas Kuznet, define economic growth as long-term ability to provide variety of economic goods to the com- munity (Suryana, 2000:64).

Economists generally give the same sense about economic growth, namely as the increase in Gross Domestic Product/ Gross National Product (GDP/GNP) without seeing whether the increase is higher or less than the population growth, or is there any change in economy structure or not (Arsyad, 1999). According to Sukirno (2004), economic growth is the development of economic activities from time to time and causing national real income changed.

The occurrence of economic growth cannot be separated from the role of existing sectors in economy. Seeing the sector that provides major role for the economic development of the region, according to Glasson (1997), one way or approach to fashion regional economy is economic base, this model can explain the structure of regional economic sector in two kinds that is base sector and non-base sector. Economic base model are emphasizing on the expansion of exports as the main source of its regional economic growth.

According to Kuznet in Todaro (2004), changes in economic structure or the structural transformation characterized by the presence of changes in percentage contributions of various sectors in economic development, that caused by the intensity of human activities and technological advanced. Changes in fundamental structure should include economic transformation in conjunction with social transformation. Understanding of the changing structure of the economy requires an understanding of the concept of primary, secondary, and tertiary sector as well as its 


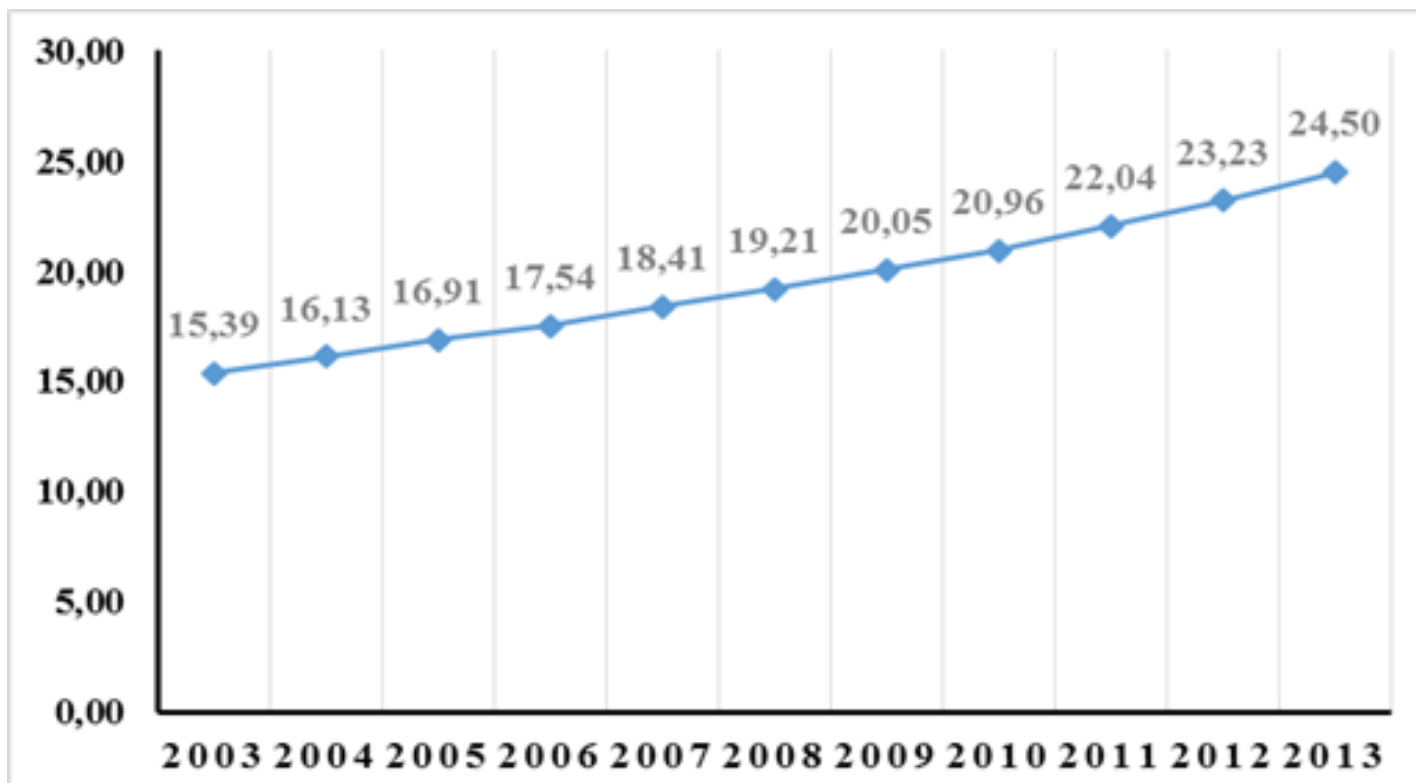

Figure 3. Top DIY PDRB at Constant Prices Year 2000, 2003-2013 (IDR. Trillion)

differences. Changes in structure that occurred include changing process from of traditionalbased economy to modern economy, from weak level economy to stronger economy.

\section{The Pattern of Economic Growth}

According to Widodo in Masli (2007), the pattern of economic growth and structure of regional economic growth based on Klassen Typology can be classified into:

1. Rapid Growth Region;

2. Retarted Region;

3. Growth Region;

4. Relatively Backward Region.

\section{Disparities of Economic Development}

Regional economic disparities development is the most common aspect in economic activity of one area. The disparity was essentially caused by differences of deposits of natural resources and demographic conditions in each region. As the result, there were differences of one area to encourage the process of economic development. Therefore, it is not surprising that in each of the countries/areas there is a region that developed and underdeveloped (Safrizal, 2008).

According to Safrizal (1997), Williamson Index is one of measurement instrument to measure the level of regional disparities which was originally used by Jeffrey G. Williamson. The calculation of Williamson index is based on GDRP data in each region using the formula. The results of measurements of the index value indicated by the numbers 0,1 or $<\mathrm{VW}<1$. If Williamson index getting closer to number 0 then the smaller the difference in economic development can be and if Williamson index getting closer to number 1 then the widening inequality of economic development. 


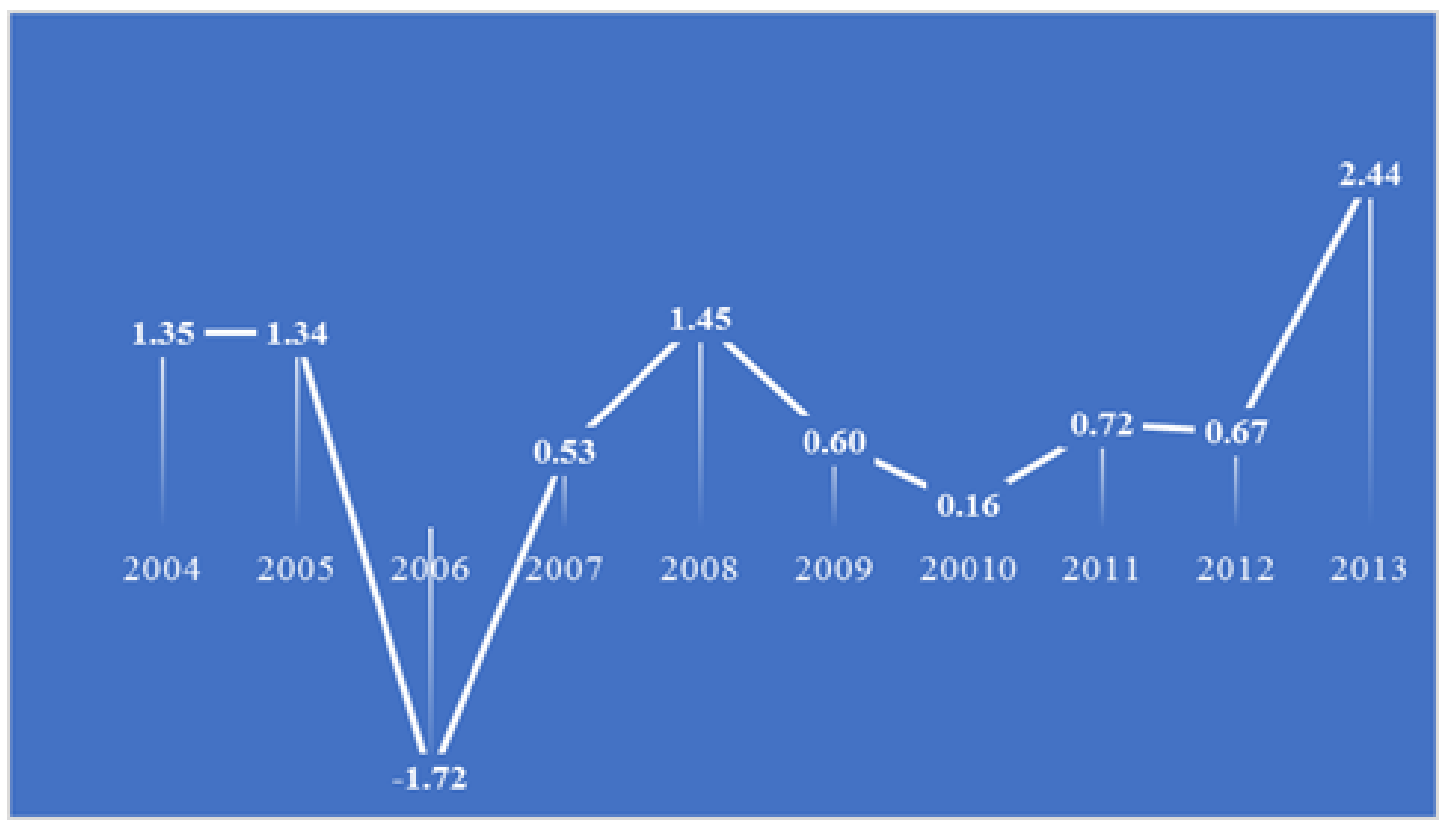

Figure 4. The Population Growth Rate of DIY Year 2004-2013 (In percentage)

\section{RESEARCH METHODS}

Data

The data used in this research were secondary data. Secondary data were consisting of time series data for 11 years beginning in 2003 until 2013 in districts/ city in Special Region of Yogyakarta (DIY) Province.

\section{Analysis Instruments}

There were two analysis Instruments being used, one instrument analysis to analyze economic growth and the other used to analyze disparities. Klassen typology used to analyze economic growth. Analysis of Klassen Typology used to describe the disparity classification for each district/ city in Special Region of Yogyakarta (DIY) Province. According to Safrizal (1997), these analyses were based on two main indicators that is average economic growth and average per capita income of an area. This analy- sis divides the four classifications of regions, each of which have different characteristics. The second analysis instrument for measuring regional disparities (between regions) by using Williamson Index and Entropi Theil. Index from Jeffery G. Williamson or Williamson Index of inequality (Safrizal, 1997: 31):

$$
C V w=\frac{\sqrt{\sum(Y i-\hat{\mathrm{y}})^{2} f i / n}}{\hat{\mathrm{y}}}
$$

Description:

CVw : Williamson Index

$\mathrm{Fi} \quad$ : total population of districts/city $-i$ (persons)

$\mathrm{n} \quad$ : population of special region of Yogyakarta (persons)

Yi $\quad$ : GDRP per capita districts/city $-i$

y $\quad$ : Average GDRP per capita Special Region of Yogyakarta (DIY) Province (Rupiahs) 


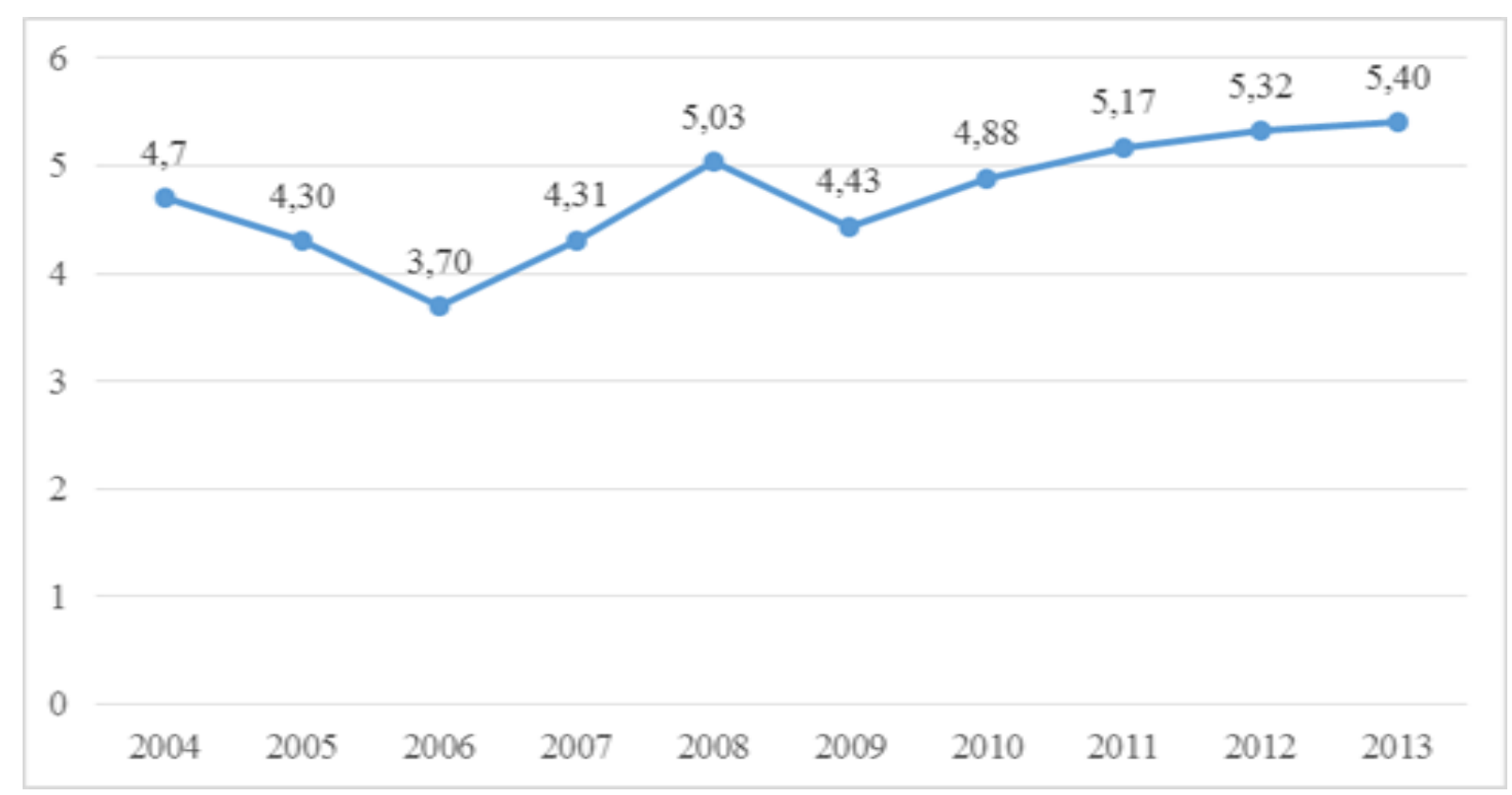

Figure 5. DIY Economic Growth 2004-2013 (In percentage)

Source: Statistic Center of Yogyakarta (analyzed data)

Entropi Theil Index as follows (Kuncoro, 2004):

$$
\text { I theil }=\sum(y j / Y) x \log (y j / Y) /(x j / X)
$$

Wherein:

I theil : Entropi Theil Index

Yj : GDRP per capita district $\mathrm{j}$

$Y \quad$ : Average GDRP per capita of Special Region of Yogyakarta (DIY) Province

$x j \quad$ : total population district $\mathrm{j}$

$X \quad$ : total population of Special Region of Yogyakarta (DIY) Province

If Entropi Theil index value $=0$ means evenly distributed and if index value getting away from zero then bigger disparities were occurred.

\section{RESULT AND DISCUSSION}

\section{The Growth and the Economy Yogyakarta}

\section{Province}

Indicators used to see the economic growth of DIY Province in this study is the GDP at Constant Prices. GRDP constant prices is the sum of the production value or the income or the expenditure assessed on based on the fixed price (the price in the base year) for one year. Figure 3 will explain how the GDP at constant prices from Yogyakarta Province during 2003 to 2013.

The trend of the development of the value of GDP during the period 2003-2013 shows an increase every year. In 2003 the DIY GDP amounted IDR. 15, 39 trillion, and then increased to IDR 24, 51 trillion in 2013. During the period 2003-2013, DIY economic performance as measured by the economic growth could grow by an average of 4.72 percent per year.

\section{The Amount and the Rate of the Population} Growth

The results of the census of population rec- 


\begin{tabular}{|c|c|c|c|}
\hline $\mathrm{R}^{\prime}$ & $\begin{array}{c}\mathrm{Y} \\
1\end{array}$ & $\mathrm{Y}_{\mathrm{ij}}<\mathrm{Y}^{\prime} \mathrm{j}$ & $Y_{i j}>Y^{\prime} j$ \\
\hline$R i j>R^{\prime} j$ & & $\begin{array}{l}\text { Quadrant III } \\
\text { Fast Growing } \\
\text { Regions }\end{array}$ & $\begin{array}{l}\text { Quadrant I } \\
\text { Fast Forward and } \\
\text { Fast Growing } \\
\text { Regions }\end{array}$ \\
\hline$R i j<R^{\prime} j$ & & $\begin{array}{l}\text { Quadrant IV } \\
\text { Relative Back- } \\
\text { ward Regions }\end{array}$ & $\begin{array}{l}\text { Quadrant II } \\
\text { the depressed } \\
\text { region }\end{array}$ \\
\hline
\end{tabular}

Note :

$\mathrm{Rij}=$ The economic growth rate in each district/ city in the province

$R^{\prime} j=$ The average economic growth rate of the Province

Yij = The GDP per capita of each district / city in the province

$Y^{\prime} j=$ The average GRDP per capita in the province

Table 1. The Classification Based on the Klassen Typology Source: Sjafrizal (2008)

orded that the number of people living in DIY in 2003 amounted to $3,162,587$ inhabitants. It increased to 3,541,922 people in 2013. The population of DIY is increasing every year with a growth rate that fluctuates.

The DIY population growth rate from 2004 - 2013 year shows the fluctuate numbers (Figure 4). Ranging from 1.35 per cent in 2003 to 2.44 percent in 2013. The lowest growth rate happened in 2006 that amounted to -1.72 percent. This situation is the impact of the earthquake that struck Yogyakarta which took many lives. Meanwhile, the highest growth rate occurred in 2013 in the amount of 2.44 percent. This means that the government's program to reduce the rate of the population growth has not been entirely successful.

\section{The Yogyakarta Economic Growth Trend}

The rate of the DIY economic growth patterns during the period of 2004-2013 shows a fairly fluctuate from the level of 4.70 percent in 2004 to 5.40 percent in 2013 (Figure 5) . Although this is still growing positively, but the DIY economy is slowing and is only able to grow 3.70 percent in 2006 . This occurred due to the wake of the rising fuel prices in 2005 and the impact of the earthquake that struck Yogyakarta in May 2006 as well. In 2009 the economy is also slowing from 5.03 percent to 4.43 percent. However, by the time, the DIY economy was recovering slowly seen by the economic growth which reached the level of 5.17 percent to 5.40 percent during 2010-2013. The rate of the growth in 2013 became the highest growth levels that can be achieved by DIY during the years 2004-2013. 


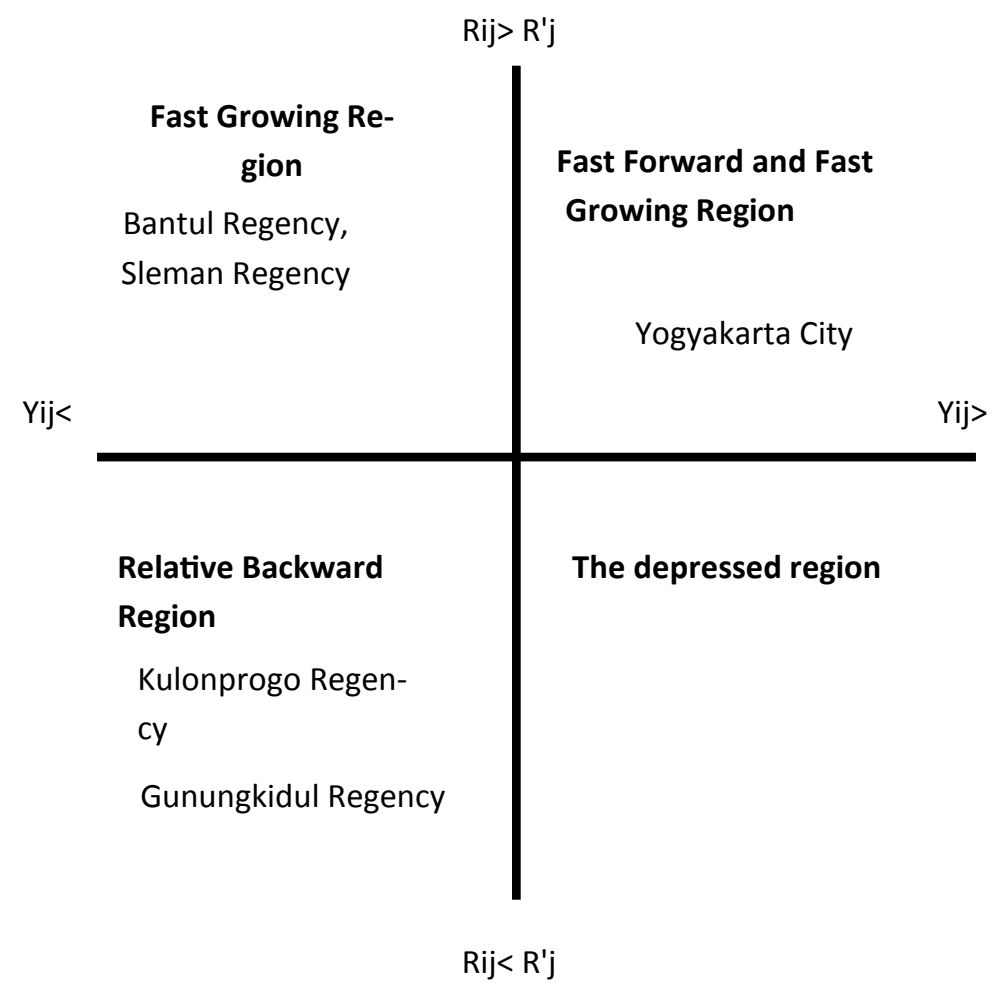

Figure 6. The Classification of Regency / City by Typology Klassen

\section{The Classification of Regency/ City in Yogya- karta Province according to the Klassen Ty- pology}

The Klassen Typology analysis is used to determine the illustration of the structure of the regional economic growth (Table 1) . According to Sjafrizal (2008), the use of this analysis tool can bring up four classifications of the growth in each region which are the rapid growth region, the depressed region, the developing region, and the relatively backward region (Figure 6).

The Rapid Growth Region is a region experiencing the GDP growth rate and per capita income that are higher than the average across the regions. Basically, the region is the most developed area, both on the level of the development and the speed of the economic growth. Commonly this region is one that has a huge po- tential that has been utilized for the prosperity of the local communities because it is expected that the region will continue to grow in the future.

The depressed region is a relatively developed region but in recent years the rate of the growth is getting slowly as a result of the suppression of the main activities of the region concerned. Therefore, although this region is developing but in the future the growth will not be so fast, despite the potential for the development owned is basically very large.

The fast growing region is basically a region that has a huge development potential but it has not been processed properly yet. Therefore, despite it has a high economic growth rate, but the level of per capita income reflecting the stage of the development is still relatively low. Moreover, the future of this region is expected to be 


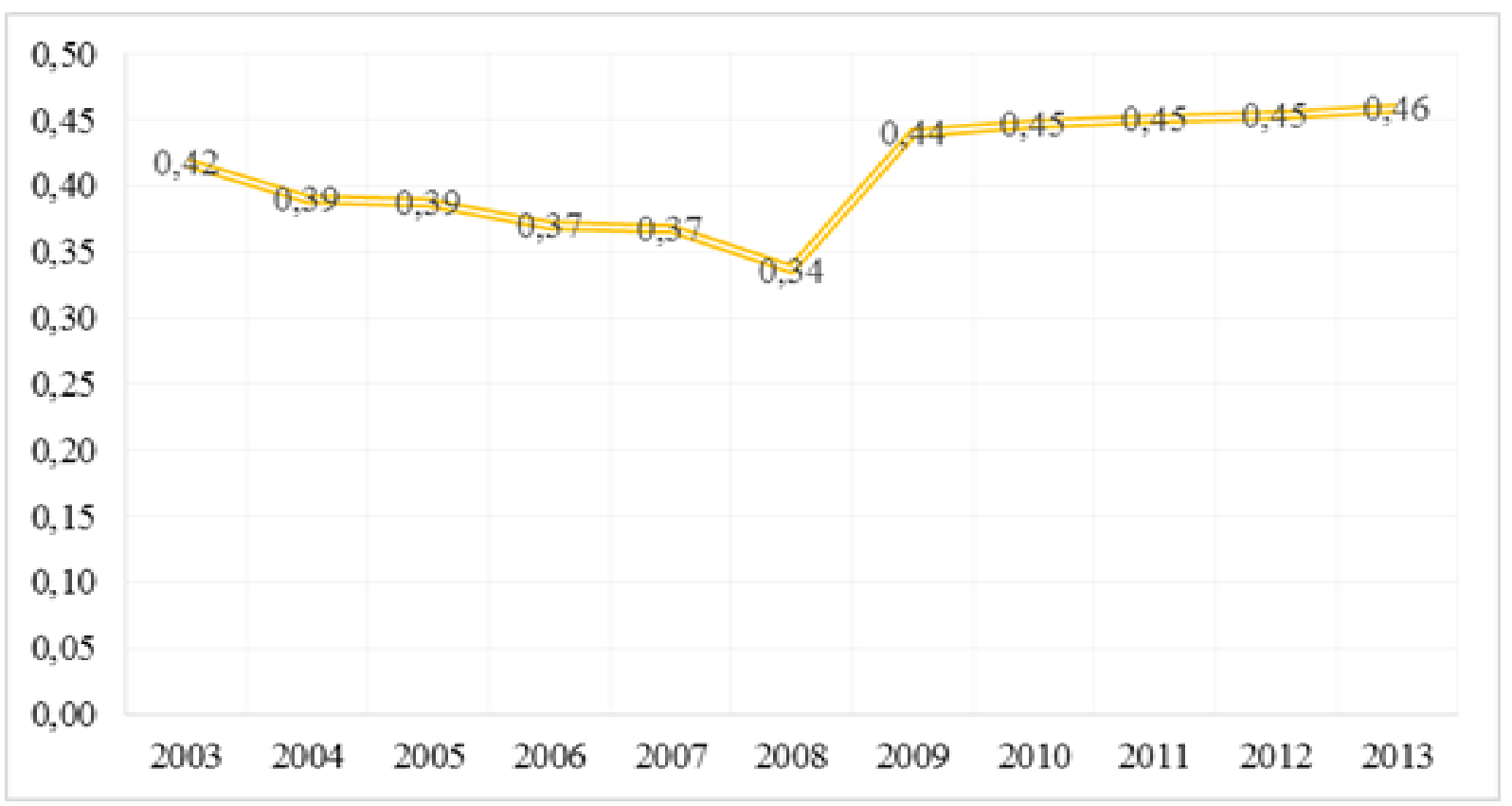

Figure 7. Williamson Index Developments in Yogyakarta Province in 2003-2013

able to grow rapidly to catch up with the developed regions.

The Relatively Backward Region is a region that has the growth rate and per capita income which are lower than the average of the other regions. This means that the level of the prosperity of the society and the level of the economic growth in this region are still relatively low. However, it does not mean that the region will not be able to develop in the future. The region that has a relatively low level of prosperity is still possible to catch up with the development of economic infrastructure, education, and society knowledge.

From the results of the classification according to the klassen typology (Figure 6), the region which belongs to the category of fast forward and fast growing region is the city of Yogyakarta, while the regions that are lagging behind is Kulonprogo and Gunungkidul Regencies. The remaining regency of Bantul and Sleman enter the fast growing category.

\section{The Level of Regional Inequality, Inter Dis- trict / Municipality in the Province of DIY based on Williamson Index}

The measurement result by Williamson index values is indicated by the numbers 0 to 1 or $0<\mathrm{IW}<1$. If the index Williamson moves approaching 0 , it means the smaller the inequality of the economic development. On the other hand, if the index Williamson is getting very close to 1 , the greater the imbalance of the economic development.

The trend on figure 7 indicates the inequality of the economic development based on the Williamson Index in Yogyakarta province. In the years 2003-2008, the inequality value shows a decreasing trend from 0.42 in 2003 dropped to 0.34 in 2008. It means that the development 


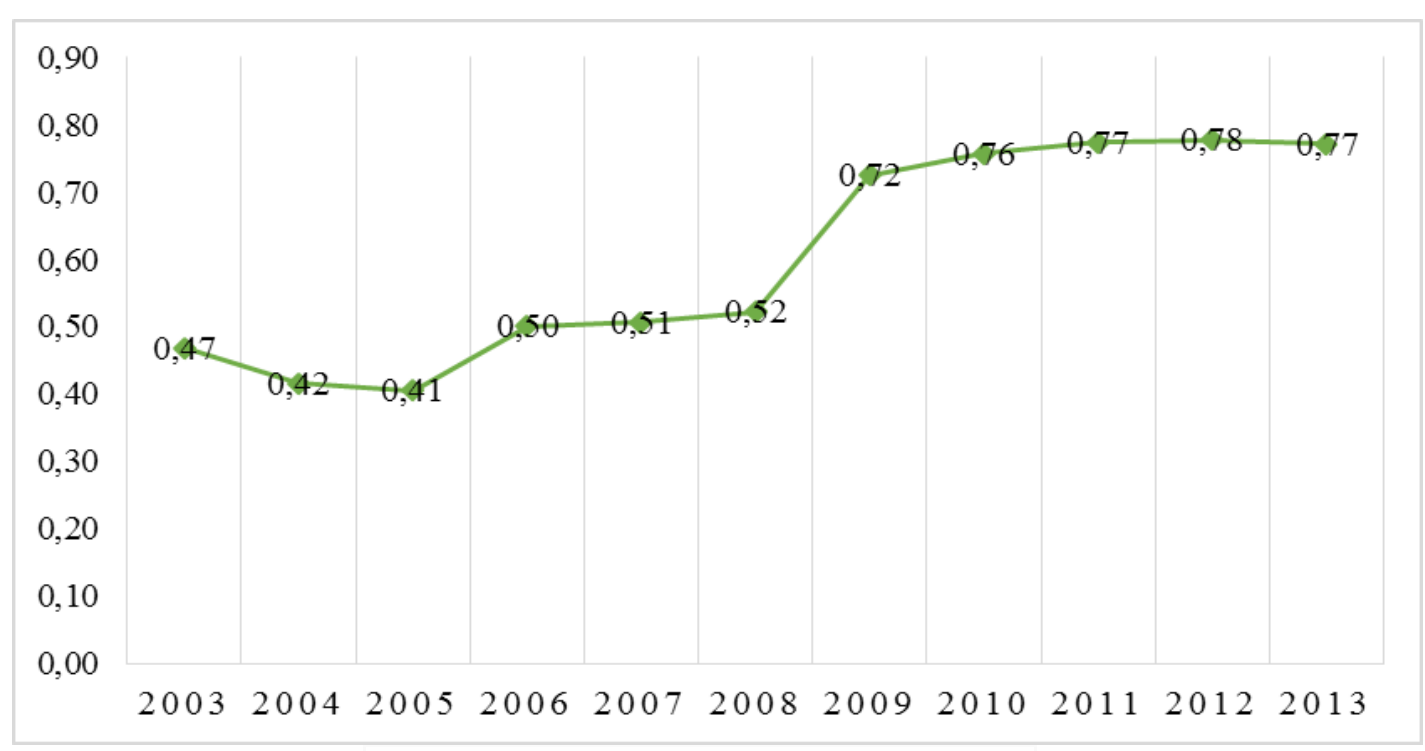

Sumber: BPS DIY (data diolah)

Figure 8. The Development of Entropy Theil Index in Yogyakarta Province in 2003-2013.

Source: Statistic Center of Yogyakarta (analyzed data)

among regency/ city in the province more evenly, but in 2008-2013 the inequality index showed an increasing pattern up to 0.46 in 2013 . It shows that the development among regency/ city in the province is getting inequal. Although the index shows a fluctuating pattern, the inequality index always shows a position below 0.5 . This means that the inequality among the regencies/ cities in the province can still be said to be small so that the development among the regencies/ cities in the province can still be said to be equally distributed. The Williamson index in the year 2008 to 2009 has increased very extreme. It is influenced by the different potential resources owned by each region such as natural resources, human resources, artificial resources, and social resources. This is also due to the differences in taxes in each region that affect the local revenue (PAD).

\section{The Level of Regional Inequality, Inter Dis- trict / Municipality in the Province of DIY based on based Entropy Theil}

If the value of entropy Theil index is 0 , then it shows the perfect evenness and if the index moves further away from 0 then there is a greater inequality. This means that a region which has a higher value of entropy Theil index is categorized as an increasingly unbalanced development (Sjafrizal, 1997: 31).

Figure 8 shows that the pattern of entropy Theil index tends to increase every year. In 2003 the rate was 0.47 and the increase up to 0.77 in 2013. The figure on the Entropy Theil index indicates that the value is getting away from zero. It means that there is a greater disparity among districts / municipalities in the province of DIY. It concludes that there is a high development gaps among the district / city in the province. 


\section{CONCLUSION}

The first conclusion from this study is that the rate of the economic growth in Yogyakarta during the period 2004-2013 shows a pattern with the levels from 4.70 percent to 5.40 percent. The results of the classification according to the Klassen typology indicates the region that belongs to the category of advanced and fastgrowing region is Yogyakarta city, while the regions that are lagging behind is both Kulonprogo Gunungkidul regencies. The remaining regencies of Bantul and Sleman belong to the fast growing category. The second conclusion is that the development of inter-regencies / cities in the province is getting more evenly, but in 2008-2013 the index indicates a pattern rising inequality. It shows that the development in the districts/ cities in the province increasingly uneven. Figures on the Entropy Theil index show the value that moves away from zero. It means that there is a greater disparity among districts/ cities in the province of DIY. It concludes that there is a high development gaps among the districts/ cities in the province. This study is in line with the previous research conducted by Noviana (2014) which states that the income inequality among the regencies/ cities in Yogyakarta is hight.

\section{REFERENCES}

Arsyad, Lincolin. 1999. Pengantar Perencanaan dan Pembangunan Ekonomi Daerah. Badan Penerbit Fakultas Ekonomi Yogyakarta.

Arsyad, Lincolyn. ed. 2004. Ekonomi Pembangunan. Cet. 2. Yogyakarta : STIE YKPN.
Badan Pusat Statistik Provinsi Daerah Istimewa Yogyakarta.2003.Daerah Istimewa Yogyakarta Dalam Angka Tahun 2003. Yogyakarta : BPS Provinsi D.I. Yogyakarta.

Badan Pusat Statistik Provinsi Daerah Istimewa Yogyakarta.2004.Daerah Istimewa Yogyakarta Dalam Angka Tahun 2004. Yogyakarta : BPS Provinsi D.I. Yogyakarta.

Badan Pusat Statistik Provinsi Daerah Istimewa Yogyakarta.2005.Daerah Istimewa Yogyakarta Dalam Angka Tahun 2005. Yogyakarta : BPS Provinsi D.I. Yogyakarta.

Badan Pusat Statistik Provinsi Daerah Istimewa Yogyakarta.2007.Daerah Istimewa Yogyakarta Dalam Angka Tahun 20062007. Yogyakarta : BPS Provinsi D.I. Yogyakarta.

Badan Pusat Statistik Provinsi Daerah Istimewa Yogyakarta.2009.Daerah Istimewa Yogyakarta Dalam Angka Tahun 2008. Yogyakarta : BPS Provinsi D.I. Yogyakarta.

Badan Pusat Statistik Provinsi Daerah Istimewa Yogyakarta.2010.Daerah Istimewa Yogyakarta Dalam Angka Tahun 2009. Yogyakarta : BPS Provinsi D.I. Yogyakarta.

Badan Pusat Statistik Provinsi Daerah Istimewa Yogyakarta.2011.Daerah Istimewa Yogyakarta Dalam Angka Tahun 2010. Yogyakarta : BPS Provinsi D.I. Yogyakarta.

Badan Pusat Statistik Provinsi Daerah Istimewa Yogyakarta.2012.Daerah Istimewa Yogyakarta Dalam Angka Tahun 2011. Yogyakarta : BPS Provinsi D.I. Yogyakarta.

Badan Pusat Statistik Provinsi Daerah Istimewa Yogyakarta.2013.Daerah Istimewa Yogyakarta Dalam Angka Tahun 2012. Yogyakarta : BPS Provinsi D.I. Yogyakarta.

Badan Pusat Statistik Provinsi Daerah Istimewa Yogyakarta.2014.Analisis Produk

Badan Pusat Statistik Provinsi Daerah Istimewa Yogyakarta.2014.Daerah Istimewa Yogyakarta Dalam Angka Tahun 2013. Yogyakarta : BPS Provinsi D.I. Yogyakarta. 
Badan Pusat Statistik Provinsi Daerah Istimewa Yogyakarta.2014.Statistik Daerah Istimewa Yogyakarta 2014. Yogyakarta : BPS Provinsi D.I. Yogyakarta.

Barika. 2012. Analisis Ketimpangan Wilayah Kabupaten/Kota di Provinsi Bengkulu Tahun 2005-2009. Jurnal Ekonomi dan Perencanaan Pembangunan Volume 04 No 03 Januari-Juni 2012.

Caska dan Riadi. 2008. Pertumbuhan dan Ketimpangan Pembangunan Ekonomi antar Daerah di Provinsi Riau. Jurnal Industri dan Perkotaan 12, 1629-1642.

Domestik Regional Bruto Daerah Istimewa Yogyakarta 2009 - 2013. Yogyakarta : Bappeda BPS Provinsi D.I. Yogyakarta.

Glassson, John.1997.Pengantar Perencanaan Regional,diterjemahkan Paul Sitohang. Jakarta:Fakultas Ekonomi Universitas Indonesia.

Krisnantiya, Narina. 2014. Faktor-faktor yang Mempengaruhi Ketimpangan Antar Wilayah di Provinsi Jawa Timur dan D.I. Yogyakarta. FEB UNDIP.

Kuncoro, M. 2004. Otonomi dan Pembangunan Daerah: Reformasi, Perekonomian, Strategi dan Peluang. Jakarta : Erlangga.

Kuncoro, Mudrajad. 2004. Otonomi dan Pembangunan Daerah. Jakarta : Erlangga.

Kusuma, Rendi Hangga. 2011. Analisis Struktur Pertumbuhan Ekonomi dan Ketimpangan Pendapatan Antar Daerah di Provinsi Jawa Tengah Tahun 2004-2008.FFE UNS.

Masli, Lili. Analisis Faktor-faktor yang mempengaruhi Pertumbuhan Ekonomi dan Ketimpangan Regional antar Kabupaten/ Kota di Provinsi Jawa Barat. Jakarta: STIE STAN IM.
Noviana, Devi Nurita. 2014. Analisis Tingkat Pertumbuhan Ekonomi dan Tingkat Ketimpangan Pendapatan Antar Kabupaten/Kota di DIY Tahun 2003-2012. FEB UNDIP.

Pirade, Ramon Diaz. 2006. Bebberapa Faktor yang Mempengaruhi Pertumbuhan Ekonomi di Jawa Timur. UPN Veteran Surabaya.

Sjafrizal.2008.Pertumbuhan Ekonomi dan Ketimpangan Regional Wilayah Indonesia Bagian Barat. Jurnal Buletin Prisma.Jakarta.

Sukirno, Sadono. 2004. Ekonomi Pembangunan: Proses, Masalah dan Dasar Kebijakan. Jakarta : LPFE UI.

Sukirno, Sadono.2006.Pengantar Makro Ekonomi.Jakarta:Raja Grafindo Persada.

Suryana. 2000. Ekonomi pembangunan: Problematika dan Pendekatan Edisi Pertama. Penerbit Salemba Empat.

Sutarno dan Kuncoro. 2003. Pertumbuhan Ekonomi dan Ketimpangan Antar Kecamatan di Kabupaten Banyumas Tahun 19932000. Jurnal Ekonomi Pembangunan Kajian Ekonomi Negara Berkembang Hal 97-110.

Syafrizal. 1997. Pertumbuhan Ekonomi dan Ketimpangan Regional Wilayah Indonesia Bagian Barat. PRISMA Maret 1997 hal 2738. Yogyakarta : LP3ES.

Tarigan, Robinson. 2007. Ekonomi Regional. Jakarta : PT Bumi Aksara.

Todaro, Michael P. 1994. Pembangunan Ekonomi di Dunia Ketiga. Jakarta : Erlangga.

Todaro, 2000. Pembangunan Ekonomi di Dunia Ketiga (Edisi ketujuh). Jakarta : Erlangga. 